Logos Universality Mentality Education Novelty: Political Sciences and European Studies

ISSN: 2284-5968 | e-ISSN: 2501-0417

Covered in: ERIH PLUS, CEEOL, HeinOnline, Index Copernicus, CrossRef, CrossCheck, J-Gate, Google Scholar, Ideas RePeC, Econpapers, Socionet, KVK, WorldCat.

2020, Volume 6, Issue 2, pages: 38-46 | doi: 10.18662/lumenpses/6.2/22

\section{Pilot Judgments Delivered by the European Court of Human Rights against Romania}

\section{Crina Mihaela VERGA ${ }^{1}$}

${ }^{1}$ Lecturer Ph.D., "George Bacovia" University of Bacau, "Al.I.Cuza" University of Iasi, Romania, crina verga2000@yahoo.com, 0040740292978
Abstract: The article defines first the concept of pilot decision. Then it details the procedure employed in case of systemic or systematic violations of any right provided by the European Convention on Human Rights. Some relevant pilot judgments against certain member states of the Council of Europe are highlighted. Next, two pilot judgments delivered against Romania (Maria Atanasiu and Others v. Romania and Rezmives and Others v. Romania) are thoroughly examined. Finally, some relevant opinions on the subject are expressed. The issue is very topical for the Romanian state and the specialists in the field, precisely because of the consequences determined by the two analyzed pilot judgments.

Keywords: pilot judgements; European Court of Human Rights; Romania.

How to cite: Verga, C.M. (2020). Pilot Judgments Delivered by the European Court of Human Rights against Romania. Logos Universality Mentality Education Novelty: Political Sciences and European Studies, 6(2), 38-46. doi: 10.18662/lumenpses/6.2/22 


\section{Introduction}

The European Convention of Human Rights and Fundamental Freedoms, a document signed in 1950, established the first procedure and an international court where human rights complaints could be addressed (Ciucă, 2018, 2019). This court has created the most developed and most extensive jurisprudence compared to any other international system in the world (Sandu, 2017).

There are a lot of applications lodged with the Court which are repetitive or "clone" cases, characteristic of a systemic or structural dysfunction at internal level. The Court had to look for methods of efficiently processing such applications, therefore the introduction of the priority criteria and the pilot-judgement procedure, which has been expressly stated in article 61 of the Rules of Court, introduced in 2011.

\section{Problem Statement}

The procedure mentioned above was conceived as a method to allow not only the identification of systemic or structural problems, which are the basis of repetitive applications, but also the imposition, on the states concerned, to solve the respective problems.

In the current case law, a systemic problem refers to a situation that affects many people and results from a deficiency of the law or a bad administrative practice, which requires a legislative change, accompanied by the adequate administrative and budgetary measures.

A structural problem is one that results from a system malfunction, usually due to insufficient budgetary or organizational resources.

\section{The procedure of pilot judgement - legal basis and case law}

Before 2009, the examination of applications by the ECHR was carried out in chronological order. After that date, the new review modality is based on seven priority categories, which allow the Court to examine the applications based on their importance and urgency, so that requests for serious human rights violations can be examined more quickly.

So, under Rule 41 amended (ECHR, 2020, p. 21), "in determining the order in which cases are to be dealt with, the Court shall have regard to the importance and urgency of the issues raised on the basis of criteria fixed by it. The Chamber, or its President, may, however, derogate from these criteria so as to give priority to a particular application". 
In these seven priority categories, after urgent requests, there is the pilot or principle decision. Therefore, if numerous claims based on the same issue are brought before the Court, it may decide to settle one or more of them with priority in the pilot-judgement procedure.

In February 2011, the Court introduced in its Regulation the Rule 61clarifying how to deal with the possible systemic or structural human rights infringement, taking into account the experience accumulated by the Court in applying this procedure in previously solved cases.

In accordance with Rule 61, the pilot-judgement procedure includes several distinct stages. The first one is the consultation of all the involved parties on the appropriate way of applying the procedure concerned.

Then, the Court shall establish the necessary measures that must be taken by a state internally and a deadline to be respected.

Another relevant phase is the adjournment of similar cases pending the adoption of remedial measures. If the latter are not adopted by the state involved, the Court resumes proceedings in those suspended cases. The Court may also, at any time, resume its examination of any case that has been adjourned if there are urgent interests of justice which require such a solution.

The effective execution of a pilot decision is the final phase of this procedure. So, the states have to repair the existing infringement and they have the freedom to use the most appropriate ways to be applied under the supervision of the Committee of Ministers.

According to the Article 46 of the European Convention for the Protection of Human Rights and Fundamental Freedoms (CE, 1950), which refers to the binding force and the execution of judgements, if the Committee of Ministers considers that the supervision of the execution of a final judgment is hampered by a problem of interpretation of the judgment, it may refer the matter to the Court for a ruling on the question of interpretation. Such a decision can be taken only by two thirds of the Committee's members.

In a pilot judgment, the objectives of the Court are: to establish a violation of the European Convention in a given case; to discover the deficiency according to the domestic legislation underlying the infringement; to provide clear guidance to the state concerned in order to remove this dysfunction; to create an internal remedy to resolve pending cases or to find solutions in all such cases pending before the Court; to offer faster solutions to all applicants compared to the situation in which they would have obtained satisfaction through an individual decision; to relieve the Court of numerous similar complaints by issuing a judgment, whose measures are 
required for a large number of cases, which have as their cause a systemic or structural problem.

The pilot judgement determines the respondent state to comply with the measures imposed by the Court and to resolve multiple cases resulting from the same root, strengthening the principle of subsidiarity, which underlines the Convention system.

As it has been judiciously mentioned in legal literature, this procedure represents in fact a combining of individual and general redress (Buyse, 2009).

The Court has delivered many pilot decisions in accordance with article par. 3 of the Court Regulation, such as: Dimitrov and Hamanov v. Bulgaria and Finger v. Bulgaria (May 10, 2011), Ananyev and Others v. Russia (January 10, 2012), Ümmühan Kaplan v. Turkey (March 20, 2012), Michelioudakis v. Greece (April 3, 2012), Kurić and Others v. Slovenia (June 26, 2012), Manushaqe Puto and Others v. Albania (July 31, 2012), Glykantzi v. Greece (October 30, 2012), Torreggiani and Others v. Italy (January 8, 2013), MC and Others v. Italy (September 3, 2013), Gerasimov and Others v. Russia (July 1, 2014), Ališić and Others v. Bosnia and Herzegovina, Croatia, "Former Yugoslav Republic of Macedonia", Serbia and Slovenia (July 16, 2014), Rutkowski and Others v. Poland (July 7, 2015), Gazsó v. Hungary (July 16, 2015), Neshkov and Others v. Bulgaria (January 27, 2015), Varga and Others v. Hungary (March 10, 2015), Sukachov v. Ukraine (January 30, 2020).

The European Court delivered also two pilot judgments in respect of Romania: Maria Atanasiu and Others versus Romania (2010); Rezmives and Others versus Romania (2017).

In addition to the pilot judgments, the Strasbourg Court has created, in its case law, another, more numerous subcategory of cases: semi-pilot judgments. The main purpose of the latter is to determine the systemic or structural problem in question, in order to facilitate the solution of that problem at national level. Such judgments were, for example: Kauczor v. Poland (February 3, 2009), Driza v. Albania (November 13, 2007), Gulmez v. Turkey (May 20, 2008), Sarica and Dilaver v. Turkey (May 27, 2010), Iacov Stanciu v. Romania (July 24, 2012), the Association "21 December 1989" and Others v. Romania (May 25, 2011), Center for Legal Resources on behalf of Valentin Campeanu v. Romania (July 17, 2014), Reformed Church Foundation for Student Housing and Stanomirescu v. Romania (January 7, 2014), Vlad and Others v. Romania (November 26, 2013), Viasu v. Romania (December 9, 2008), Faimblat v. Romania (January 13, 2009), 
Katz v. Romania (January 20, 2009), Denes and Others v. Romania (March 3, 2009).

The differences between the two types of judgments are small and relate mainly to procedural matters. Thus, semi-pilot decisions have some characteristics: they are not described as pilot decisions; they establish the systemic/structural problem in the matter, in order to determine its solution internally; they do not fix the general measures in charge of the state, which is free to establish them; as a rule, they do not suspend repetitive complaints.

\section{Decisions pronounced against Romania}

\subsection{Maria Atanasiu and Others versus Romania (2010)}

The Court delivered a judgment in the pilot case Maria Atanasiu and Others v. Romania (Decision of October 12, 2010, final on January 12, 2011), in which it found that there was a systemic problem with the inefficient restitution or compensation mechanism.

This decision referred to the restitution or compensation of properties nationalised or abusively confiscated by the state before 1989, during the communist period in Romania.

In the above mentioned judgment, the Court ruled that the Romanian State had the obligation, within a certain period, initially established at 18 months and subsequently extended until May 12, 2013, to adopt general measures, in order to streamline the mechanism regarding retrocessions or damages, for ensuring a concrete, effective protection of the right to property in these cases (Ignătescu, 2019).

The court also decided to suspend the settlement of any similar cases regarding property until the expiry of the time limit for taking general measures.

On May 16, 2013, in fulfilling the state's obligation to take general measures, as established by the Court through the pilot case Maria Atanasiu and Others v. Romania, the Parliament adopted Law no. 165/2013 regarding the measures for completing the process of retrocession, in kind or equivalent, of the buildings taken over abusively during the communist regime in Romania.

By the judgement given in the case Preda and Others versus Romania (2014), the Court established the consequences resulting from the adoption of Law no. 165/2013. Thus, the Court considered that, in principle, the above mentioned law established an effective and accessible procedure for remedying the violation of the right to the protection of property in the aforementioned cases. The Court also ruled that the 
applicants having their cases lodged with the Court at the date of legal effects of Law no. 165/2013 were to abide as well by the procedure provided by this law (ECHR, 2011).

The ECHR also ruled against Romania regarding the restitution of the buildings taken over abusively during the communist regime. This is the case of Ana Ionescu and Others versus Romania, in which the applications of several complainants were connected. The final amount granted as compensation exceeded 2.7 million euros. The judgment was delivered on February 26, 2019.Hence, one reaches the conclusion that the mechanism established through the legislation developed following the 2010 pilot decision, was not a successful one, since the framework law on the matter has undergone numerous amendments, the last of which is Law no. 219/2020. Likewise, the Law no. 165/2013 was modified repeatedly by the numerous Constitutional Court decisions (Lower House, n.d.).

\subsection{Rezmives and Others versus Romania (2017)}

The main problem in this case was overcrowding and precarious conditions in prisons, including failure to provide adequate medical care.

The ECHR fined Romania with about 17,850 euros in the case of Rezmives, which was the starting point of the pilot decision. The Court did not impose any specific measures to Romania, nor did it specify amnesty or relaxation of the criminal policy.

The ECHR judges also decided to suspend trial on similar applications against Romania that had not yet been submitted to the Romanian Government until the state presented the appropriate measures and to continue its examination of ongoing applications.

The Court held that Article 3 (prohibition of torture) and Article 13 (right to an effective remedy) of the Convention mentioned above had been violated.

It is worth noting that the ECHR had advanced a period of 6 months for Romania to present a clear plan for the putting into practice of general measures to reduce overpopulation and make better conditions of detention.

By the decision set out above, the Romanian State also must introduce a preventive remedy and another one for the compensation the inhuman and degrading conditions of imprisonment.

In this regard, on January 17, 2018, the Government of Romania approved the 2018-2024 Calendar of measures for solving prison overcrowding and the conditions of detention. 
In March 2018, the Romanian executive approved the memorandum on the theme of the Principle Agreement on borrowing from the Development Bank of the Council of Europe, up to 223 million euros, in order to support the project "Investments in prison infrastructure". Thus, the financing of certain measures provided in the 2018-2024 Calendar of Measures mentioned above was ensured.

Likewise, the Parliament adopted Law no. 169/2017 for amending and supplementing Law no. 254/2013 on the execution of custodial punishments and measures ordered by the judicial bodies during criminal process, which provided for early release from detention facilities for improper conditions.

The law mentioned above was repealed, for the most part, by Law no. 240/2019, fact which proves its ineffectiveness.

"Continuing the project of investments in detention facilities and of modernization and extension of locations" was set as measure no. 20, in the chapter on Justice, the section on Fundamental Rights, encompassed in the 2017-2020 Government Program.

\section{Conclusions}

The pilot-decision procedure was conceived as a method to allow the identification of systemic or structural problems, which are the source of repetitive cases and which impose to the respective states to solve such problems.

In this proceeding, the Court has not only the function to decide if there has been a violation of the Convention in a given case, but also to determine the systemic or structural problem and to provide precise suggestions on the measures which the government concerned must take to remedy the problem.

However, the condemned State has the liberty to choose how it will fulfil its obligations according to relevant legislation.

One of the essential features of the pilot-decision procedure is that it allows the Court to suspend for a certain period the applications that are the subject of the procedure, provided that the government concerned takes the necessary internal measures quickly, in order to comply with the judgement.

However, the Court may resume the examination of suspended applications whenever the interests of the administration of justice impose it. The Court uses this procedure with great flexibility, as not any group of repetitive requests falls into the category of very serious human rights violations and requires the pilot-judgement procedure to be applied. 
Pilot Judgments Delivered by the European Court of Human Rights against ... Crina Mihaela VERGA

In Romania, in the case Maria Atanasiu and Others versus Romania, the remedy given by Law no.165/2013 was not effective enough, since the law has been changed many times and Romania was convicted again in a case having identical object as the cases which led to the pilot decision. At the same time, in the case Rezmives and Others versus Romania, the framework law adopted (Law no. 169/2017) was largely repealed by Law no. $240 / 2019$, for a better implementation of the pilot decision given by the Court in Strasbourg.

Therefore, the legislation adopted for the execution of judgments against Romania has very often been amended or even abrogated for the most part, fact which highlights its lack of ineffectiveness.

\section{References}

Buyse, A. (2009). The pilot judgment procedure at the European Court of Human Rights: Possibilities and challenges. Nomiko Vima (The Greek Law Journal), 57, 1890-1902. https://ssrn.com/abstract=1514441

Ciucă, A. (2018). Drept international public [International public law]. Lumen.

Ciucă, A. (2019). Statut personal și naționalitate in dreptul internațional privat [Personal status and nationality in private international law]. Lumen.

Council of Europe (CE). (1950). Convention for the Protection of Human Rights and Fundamental Freedoms and Additional Protocols. https://www.echr.coe.int/Documents/Collection_Convention_1950_EN G.pdf

European Court of Human Rights (ECHR). (2011). Maria Atanasiu and Others versus Romania. https://hudoc.exec.coe.int/ENG\#\{\%22EXECIdentifier\%22:[\%22004$13025 \% 22]\}$

European Court of Human Rights (ECHR). (2020). Rules of the Court. https://www.echr.coe.int/Documents/Rules Court ENG.pdf

Ignătescu, C. (2019). Abuzul de drept [The abuse of rights]. Lumen.

Lower House. (n.d.). Introducere [Introduction]. http://cdep.ro/pls/legis/legis pck.frame

Romanian Parliament. (2013). Legea nr. 165/2013 privind măsurile pentru finalizarea procesului de restituire, în natură sau prin echivalent, a imobilelor preluate în mod abuziv în perioada regimului comunist în România [Law no. 165/2013 regarding the measures for completing the process of retrocession, in kind or equivalent, of the buildings taken over abusively during the communist regime in Romania]. Monitorul Oficial al României, 278, 2013, May 17. 
Romanian Parliament. (2017). Legea nr. 169/2017 pentru modificarea şi completarea Legii nr. 254/2013 privind executarea pedepselor şi a măsurilor privative de libertate dispuse de organele judiciare în cursul procesului penal [Law no. 169/2017 for the amendment and completion of Law no. 254/2013 on the execution of sentences and custodial measures ordered by the judiciary during criminal proceedings ]. Monitorul Oficial al României, 571, 2017, July 18.

Romanian Parliament. (2019). Legea nr. 240/2019 privind abrogarea Legii nr. 169/2017 pentru modificarea şi completarea Legii nr. 254/2013 privind executarea pedepselor şi a măsurilor privative de libertate dispuse de organele judiciare în cursul procesului penal, precum şi pentru modificarea Legii nr. 254/2013 privind executarea pedepselor şi a măsurilor privative de libertate dispuse de organele judiciare în cursul procesului penal [Law no. 240/2019 regarding the abrogation of Law no. 169/2017 for the amendment and completion of Law no. 254/2013 on the execution of sentences and custodial measures ordered by the judicial bodies during the criminal proceedings, as well as for the amendment of Law no. 254/2013 on the execution of sentences and custodial measures ordered by the judiciary during criminal proceedings]. Monitorul Oficial al României, 2019, December 20.

Romanian Parliament. (2020). Legea nr. 219/2020 pentru modificarea şi completarea Legii nr. 165/2013 privind măsurile pentru finalizarea procesului de restituire, în natură sau prin echivalent, a imobilelor preluate în mod abuziv în perioada regimului comunist în România [Law no. 219/2020 for amending and supplementing Law no. 165/2013 regarding the measures for completing the process of retrocession, in kind or equivalent, of the buildings taken over abusively during the communist regime in Romania]. Monitorul Oficial al României, 1011, 2013, October 20.

Sandu, A. (2017). Construcția socială a profesiei de consilier de probatiune [The social construction of the probation counselor profession]. Lumen. 